\title{
THE TAXONOMY OF VACCINIUM SECTION RIGIOLEPIS (VACCINIEAE, ERICACEAE)
}

\author{
S.P. VANDER KLOET \\ Department of Biology, Acadia University, Wolfville, Nova Scotia, B4P 2R6 Canada
}

\begin{abstract}
SUMMARY
Vaccinium section Rigiolepis (Hook.f.) Sleumer is revised for the Flora Malesiana region. In the introduction a short history of the genus (section) and its defining characters are presented followed by comments about Sleumer's classification for this section. Numerical techniques using features suggested by Sleumer on 'indet' specimens at Leiden counsel a more conservative approach to species delimitation and the resultant revision for this section recognizes thirteen species including three new taxa, viz., V. crinigrum, V. suberosum, and V. linearifolium. Lectotypes for V. borneense W.W. Sm. and V. leptanthum Miq. are also proposed.
\end{abstract}

Key words: Vaccinium, Rigiolepis, Malesia, new species.

\section{INTRODUCTION}

Since its inception in 1876, the genus Rigiolepis Hook.f. has been a perennial candidate for the Rodney Dangerfield 'No Respect' Award. All the other SE Asian segregates of Vaccinieae, such as Agapetes D. Don, Dimorphanthera F. Muell., and Costera J.J. $\mathrm{Sm}$. have gained widespread acceptance among botanists, but not so Rigiolepis where even the staunchest supporters, viz., Ridley (1922) and Smith (1914, 1935) could not agree on a common suite of generic characters for this taxon. Ridley (1922) argued that Rigiolepis could be separated from Vaccinium by its epiphytic habit, extra-axillary racemes and very small flowers. Unfortunately, neither small flowers nor the epiphytic habit are unique to Rigiolepis but are widespread in the Vaccinieae; indeed V. uliginosum L., the type for Vaccinium and V. crassifolium Andrews have flowers just as small as most of the taxa in Rigiolepis.

As for extra-axillary racemes, Smith (1935) was quite correct when he pointed out that neither Vaccinium nor Rigiolepis, nor indeed any Vaccinieae, have any. Inflorescences in the Vaccinieae are produced either in the leaf axils of current shoots or from axillary buds of older leaves or from ancient axillary buds on old wood. Furthermore, Rigiolepis has a propensity to produce several (3-5) perennating buds in some of its leaf axils; if all these contain floral primordia, then the result will be a fascicle of 3-5 slender rachides, each bearing 10-30 small flowers on slender pedicels (Fig. 7).

However, according to Smith (1935) the gynoecium and androecium of Rigiolepis are quite distinct: The ovary is 10-celled with septa similar, complete, and thin; the small stamens have anthers whose tubules open by a long, longitudinal cleft-like introrse pore. However, these characters are not unique to Rigiolepis. Vaccinium oldhamii Miq., 
which belongs to section Ciliata Nakai, has a 10-celled ovary whilst V. ridleyii Sleumer in section Galeopetalum (J.J. Sm.) Sleumer also has tiny stamens whose tubules also open with a cleft-like introrse pore. Indeed, the first species described belonging to this group of shrubs was placed in Gaylussacia Humb., Bonpl. \& Kunth by Blume in 1825 as $G$. lanceolata, because of its 10-locular ovary with each locule containing a single seed.

Recent molecular data from Powell \& Kron (2002) firmly roots Rigiolepis in their Agapetes clade. This SE Asian clade contains several Himalayan taxa such as Agapetes, Vaccinium section Conchophyllum Sleumer, Vaccinium section Galeopetalum as well as Rigiolepis. Whether or not to recognize this clade taxonomically shall remain moot: insufficient data based on a too small selection of Vaccinieae is the usual plaint to excuse oneself for making the hard choice. Regardless, neither the morphological nor molecular data adduced here supports generic status for Rigiolepis but sectional status as promoted by Copeland (1932), Sleumer (1941), and Stevens (1969) seems warranted not on the basis of unique features of which there is only one, i.e., a propensity to lay down multiple flower buds in leaf axils (Fig. 7). Not that every twig or taxon has multiple flora primordia in every leaf axil, but rather that every specimen will have at least one or more leaf axils with multiple flower buds regardless of rachis length.

Other features, such as long-awned bud scales, a 10-celled ovary, each cell containing one or two seeds, short anthers with cleft-like introrse pores, are not exclusive to section Rigiolepis. However, when the above are combined with floral bracts and calyx lobes that are strongly ribbed parallel to the edge (Fig. 4a) and/or attenuated rachides as well as with lanceolate leaves that terminate in long acuminate apices (Fig. 3) and older twigs with verrucose lenticels, the overall gestalt is quite sufficient for a distinct section.

Although Sleumer (1967) recognized 23 species in Vaccinium section Rigiolepis, he conceded most were difficult to distinguish from each other, partly owing to insufficient or incomplete collections and partly due to insufficient diagnostic features. Ten of the taxa he cited are known only from the type collection or collections from the type locality; for 17 taxa nothing was known about the ripe fruit or the seed. Furthermore, all the flowers in this section are quite similar in size and shape; only the calyx lobes and inflorescence bracts offer some discriminatory power, hence Sleumer's diagnostic features focus primarily on inflorescence bracts and leaf features as well as indumentum which is notoriously unreliable in this clade: innovations on the same twig of V. gaultheriifolium (Griff.) Hook.f. can be either glaucous and glabrous or glaucous, pubescent, and glandular.

To test the utility of Sleumer's classification two approaches were tried:

1) Apply his diagnostic key to 37 sheets of undetermined specimens but belonging to Vaccinium section Rigiolepis at Leiden (L) and count the number that could be identified;

2) score these 37 specimens using 16 characters from the key (Table 1), and sort through this matrix using various sorting techniques such as nearest neighbour, UPGMA, and PCA (Sneath \& Sokal, 1973) in order to determine whether or not the resultant clusters resemble known taxa. 
Table 1. Morphological characters scored for the numerical analyses.

1. Twigs of the current season: $1=$ glabrous; $2=$ pubescent; $3=$ pilose; $4=$ glandular

2. Lenticels on older twigs prominent or not

3. Perennating bud scales - length of awn in $\mathrm{mm}$

4. Leaf length in $\mathrm{mm}$

5. Leaf width in $\mathrm{mm}$

6. Leaf apex caudate or not

7. Abaxial leaf indumentum: $1=$ glabrous; $2=$ pubescent; $3=$ pilose $; 4=$ glandular

8. Venation: \# of prominent lateral/parallel veins

9. Blade reticulation: $1=$ prominent; $2=$ scarcely visible

10. Petiole length in $\mathrm{mm}$

11. Number of inflorescences per leaf axil

12. Number of flowers/inflorescence

13. Rachis length at anthesis in $\mathrm{mm}$

14. Rachis length at fruiting in $\mathrm{mm}$

15. Inflorescence indumentum: $1=$ glabrous; 2 = pubescent; $3=$ pilose; $4=$ glandular

16. Bracts, bracteoles \& calyx lobes strongly ribbed parallel to the edge or not

17. At anthesis, the calyx tube is frequently covered by a pair of particular bracts or not

\section{RESULTS}

Only three specimens could be unambiguously identified using Sleumer's (1967) key to the species of Vaccinium section Rigiolepis. One specimen, OTU 29 (Fig. 5), could not even be satisfactorily resolved by the first couplet since its prominent bracts clasp the calyx tube (Fig. 5c), just as in the inflorescence of V. suberosum Kloet (Fig. 4). Indeed, the only difference between the flowers of these two specimens (OTU 29 and OTU 7) is the prominence of the parallel ribs in the latter and the density of the fuscous pubescence in the former (Fig. 5c). Moreover, the ambiguity of the feature is highlighted in Sleumer's key where the first couplet separates those plants with well-developed parallel ribs on the calyx lobes and floral bracts (Fig. 4a) from those with none or are "but indistinctly ribbed" (Fig. 6b). Furthermore, when these specimens (OTUs 29-31) are scored as having parallel ribs on floral bracts and calyx lobes (Fig. 1) or not (Fig. 2; Table 1, characters 15 and 16) the changes in the cluster structure is dramatic: only group C, V. uniflorum J.J. Sm. remains intact in both phenograms. This cohesiveness of V. uniflorum was first noticed by Copeland (1932) who separated this taxon from Vaccinium section Rigiolepis.

Using Sleumer's (1967) characters sensu stricto, i.e., when not patently obvious ignore, then the resultant clusters (Fig. 2), not surprisingly, mimic the structure envisaged by Sleumer, viz., group A (Fig. 2, Table 2) comprises those plants with well-developed ribs on the calyx lobes and pedicular bracts (Fig. 4) e.g., V. lobbii (Ridl.) Sleumer. This group fits Rigiolepis sensu Ridl. (Ridley, 1922).

The next group to separate, viz., group B comprises OTUs 37, 8, 25, 31, 32, 33, 36, and 13, share the following features: leaves $17 \pm 4 \mathrm{~cm}$ long, $6 \pm 1 \mathrm{~cm}$ wide, bud scale awns $3 \pm 2 \mathrm{~mm}$ long; $2 \pm 1$ inflorescences in the leaf axils; rachides $5 \pm 2 \mathrm{~cm}$ long bearing $13 \pm 4$ flowers (Table 2). This description circumscribes the V. sulcatum Ridl., $V$. piperifolium Sleumer, and the acuminatissimum Miq. complex, the most widespread 


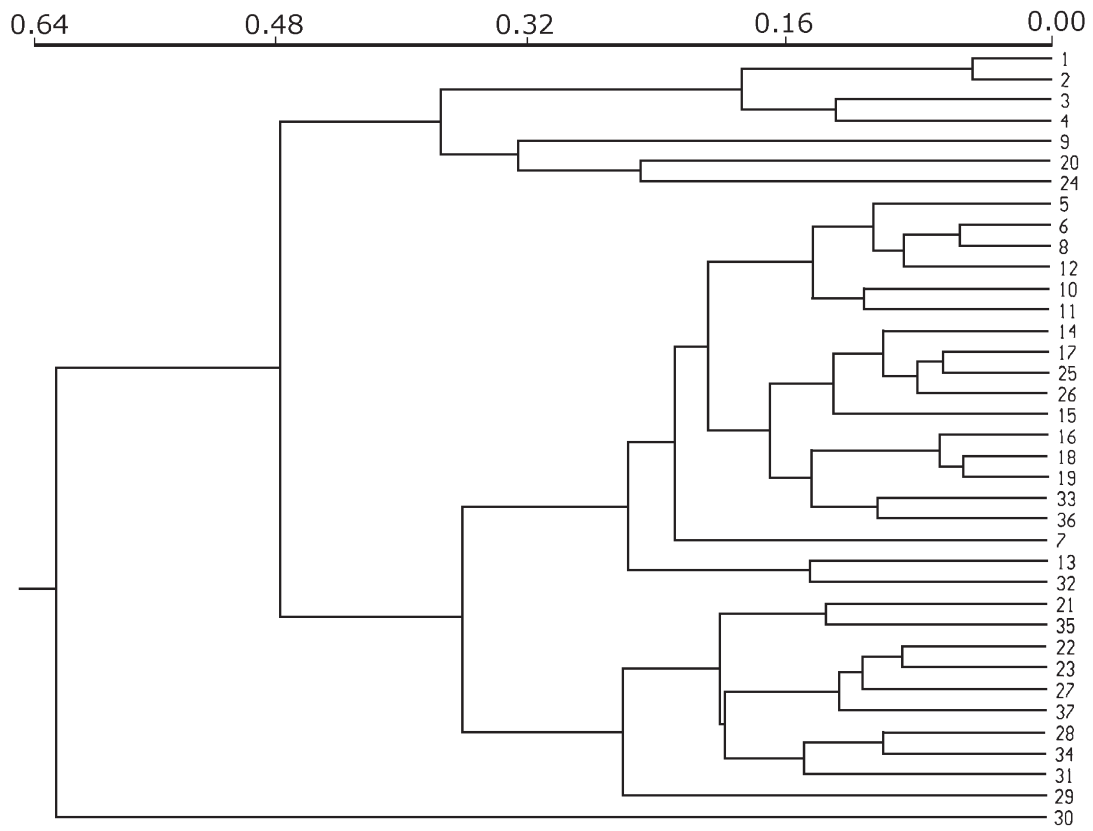

Fig. 1. Phenogram depicting clusters when characters 16 and 17 are read sensu lato, i.e., the bracts and calyx lobes are ribbed as in V. crinigrum (Fig. 5c).

Table 2. Quantitative differences (means $\pm \mathrm{SD}$ ) among the groups separated by numerical analyses and depicted in Fig. 2. Significant differences are boxed.

\begin{tabular}{lcccccc}
\hline Clusters & $\mathrm{A}$ & $\mathrm{B}$ & $\mathrm{C}$ & $\mathrm{D}_{1}$ & $\mathrm{D}_{2}$ & $\mathrm{D}_{3}$ \\
\hline Leaf length $(\mathrm{cm})$ & $11 \pm 3$ & $17 \pm 4$ & $4 \pm 1$ & $9 \pm 3$ & $14 \pm 3$ & $11 \pm 2$ \\
Leaf width $(\mathrm{cm})$ & $4 \pm 2$ & $6 \pm 1$ & $2 \pm 0.5$ & $2 \pm 1$ & $4 \pm 1$ & $3 \pm 1$ \\
Bud scale awns $(\mathrm{mm})$ & $2 \pm 1$ & $3 \pm 2$ & $1 \pm 0.3$ & $3 \pm 2$ & $2 \pm 1$ & $2 \pm 1$ \\
\# inflorescences & 1 & $2 \pm 1$ & $2 \pm 1$ & 1 & $2 \pm 1$ & $2 \pm 1$ \\
\# flowers/raceme & $4 \pm 1$ & $13 \pm 4$ & 1 & $10 \pm 4$ & $10 \pm 2$ & $12 \pm 5$ \\
Rachis length (mm) & $8 \pm 6$ & $48 \pm 20$ & 0 & $39 \pm 11$ & $26 \pm 7$ & $38 \pm 12$ \\
\hline
\end{tabular}

taxon in this section. Prominence of the plinerves and the lateral connecting nerves defines the differences among these taxa (Fig. 3).

The remaining cluster in Fig. 2 contains two distinct subgroups $\mathrm{C}$ and D. Group $\mathrm{C}$ comprises OTUs $1-4$ which share the following features: leaves $4 \pm 1 \mathrm{~cm}$ long, $2 \pm 0.5$ $\mathrm{cm}$ wide, bud scale awns $1 \pm 0.3 \mathrm{~mm}$ long; 1 or 2 flowers in the axils of leaves; rachides absent (Table 2). This description fits both V. uniflorum J.J. Sm. and V. monanthum Ridl. depending on the quantity of indumentum on the flowers; otherwise these taxa are similar. 


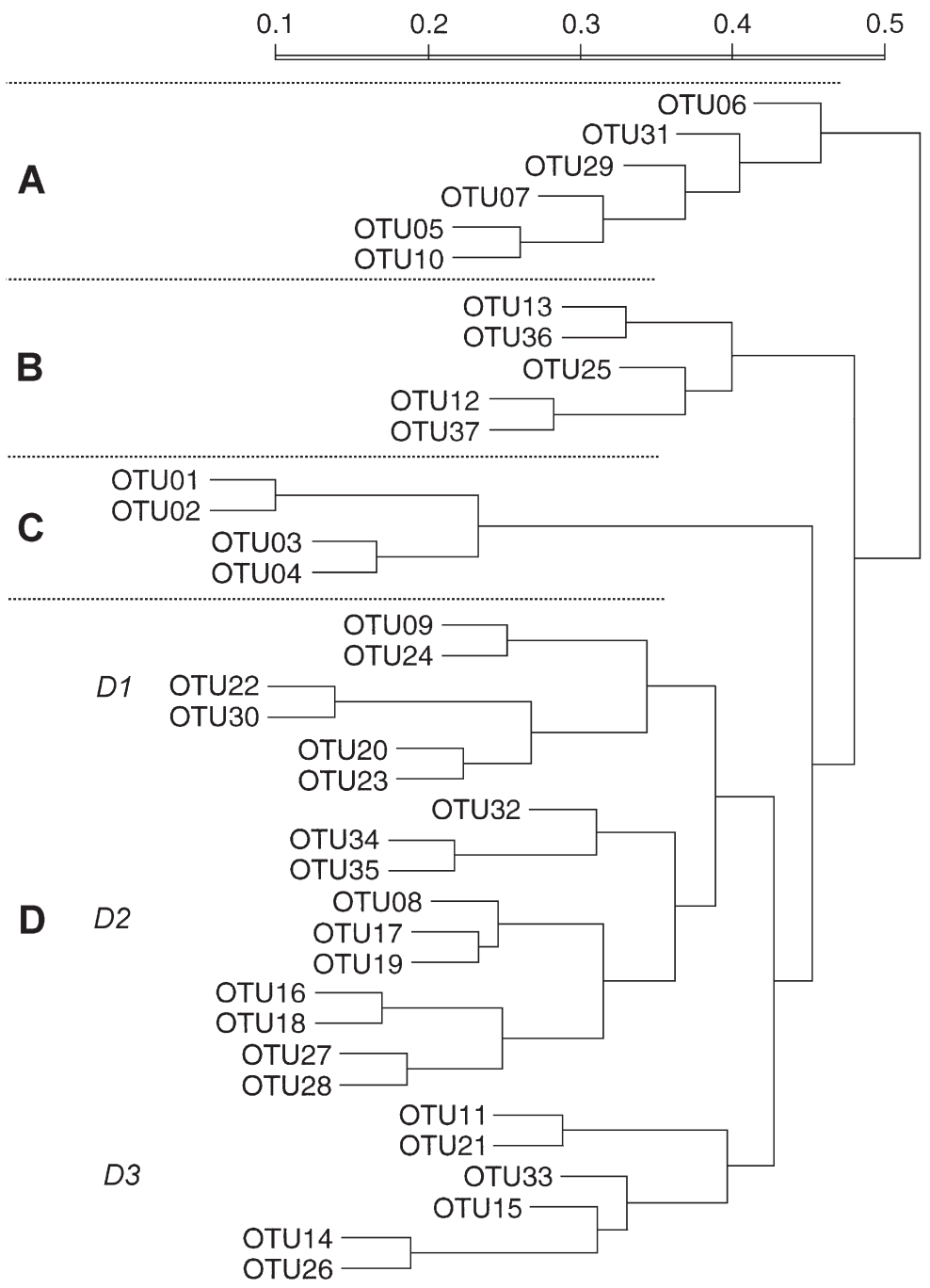

Fig. 2. Phenogram depicting clusters when characters 16 and 17 are read sensu stricto, i.e., the bracts and calyx lobes are 'not or but indistinctly ribbed' in V. crinigrum.

In spite of the chaining in group D (Fig. 2) three distinct subclusters are quite obvious: $\mathrm{D}_{1}$ has specimens with the following attributes: leaves $7 \pm 3 \mathrm{~cm}$ long, $3 \pm 2 \mathrm{~cm}$ wide, bud scale awns $2 \pm 1 \mathrm{~mm}$ long, one inflorescence in the leaf axils; rachides $4 \pm 1 \mathrm{~cm}$ long bearing $10 \pm 4$ flowers. These descriptions embrace in part such diverse taxa as V. capillipes Sleumer, V.flagellatifolium H.F. Copel., and V. filiforme (J.J. Sm.) Sleumer inter alia. Group $\mathrm{D}_{1}$ has leaves $14 \pm 3 \mathrm{~cm}$ long, $4 \pm 1 \mathrm{~cm}$ wide, bud scale awns $2 \pm 1$ mm long; $2 \pm 1$ inflorescences in the leaf axils; rachides $3 \pm 1 \mathrm{~cm}$ long bearing $10 \pm 2$ flowers (Table 2). Depending on the prominence of the plinerves and the inter-connecting secondary venation, specimens in this group fit both, $V$. filiforme or $V$. kemulense 
Sleumer. Group $\mathrm{D}_{1}$ has leaves $11 \pm 2 \mathrm{~cm}$ long, $3 \pm 1 \mathrm{~cm}$ wide, bud scale awns $2 \pm 1 \mathrm{~mm}$; has $2 \pm 1$ inflorescences in the leaf axils; rachides $4 \pm 1 \mathrm{~cm}$ long bearing $12 \pm 5$ flowers (Table 2). This group fits within the V. leptanthum Miq.-V. moultonii Merr. complex which forms the bases of Vaccinium section Rigiolepis sensu Copeland (1932).

The principal component analysis reinforces the lack of structure of this dataset: the first three components account for only $53 \%$ of the observed variation. The only significant correlation worth noting suggests that leaf size and petiole length are strongly linked to rachis length and the number of flowers per inflorescence, i.e., the larger the leaves the more flowers. Unfortunately, the higher nodes of the dendrograms (Fig. 1,2) remain unresolved.

\section{DISCUSSION AND CONCLUSIONS}

This fragmentary data and restricted sampling universe nonetheless supports Sleumer's (1967) classificatory framework for this section. However, at the specific level these data hold less promise unless indumentum and venation patterns are discounted. When young, all plant parts are pilose or densely pubescent usually with some admixture of glandular hairs; with age and concomitant shoot elongation the indumentum is either dispersed over a larger area or is even lost completely. Leaf venation is basically camptodromus (Fig. 3) but in some specimens the plinerves and their connectors are conspicuous (Fig. 3G). Whilst in others the plinerves are attenuated and more prolific (Fig. 3C) giving a vaguely pinnate impression (Fig. 3D). The type of the section, V. acuminatissimum Miq. has the former condition whilst V. megaphyllum Sleumer has the latter. Adding more fragmentary data from additional herbarium specimens adds more noise to the matrix rather than clarifying specific status. Only a long study in the field will yield a robust taxonomy.

Nonetheless several clusters are sufficiently robust to promote the following conclusions:

1) Group C, the 'uniflorum-monanthum' complex (Fig. 2) should be treated as a single taxon with $V$. uniflorum at the glabrous end and V. monanthum at the pubescent end of the gradient.

2) Clusters isolated in Fig. 2 at or below a similarity level as the V. uniflorum-V.monanthum complex should be considered species; thus group A comprises the V. lanceifolium-V. lobbii complex where only leaf size marginally separates the taxa; group B is V. acuminatissimum s.l. Group D comprises V. lepanthum s.l. and V. kemulense s.l. were the variation in indumentum, venation, and the prominence of basal glands to be discounted.

3) Isolated OTUs which did not fit into any of Sleumer's (1967) taxa and differ by at least three characters from an existing species in this section ought to be described as new, viz., OTU 29, 20, and 9.

As for the taxonomic and phylogenetic status of this section, the latest DNA evidence adduced by Kron et al. (2002) place this taxon firmly in the SE Asian clade which includes not only Agapetes D. Don but also Vaccinium section Aethopus Airy Shaw, Vaccinium section Galeopetalum J.J. Sm., and Vaccinium section Rigiolepis. 


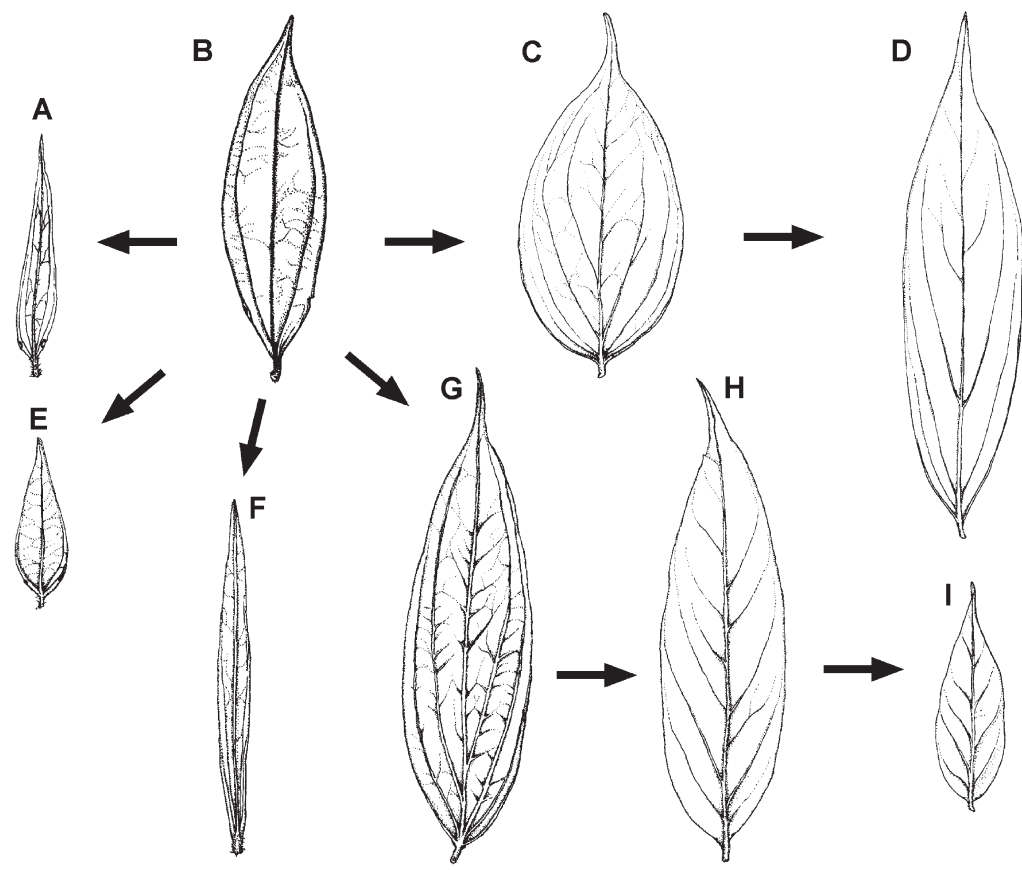

Fig. 3. Leaf shape and size of various taxa in Vaccinium section Rigiolepis. Venation is camptodromus and the arrows suggest possible routes to either blade contraction or expansion. A. Vaccinium minimiflorum; B. V. suberosum; C. V. megaphyllum; D. V. leptanthum; E. V. uniflorum; F. V. linearifolium; G. V. acuminatissimum; H. V. moultinii; I. V. andersonii.

However, until generic boundaries are resolved between Agapetes and Vaccinium, the section Rigiolepis ought to be maintained with the proviso that it contains at least three distinct subgroups, viz.:

1) Rigiolepis sensu Ridley which has plants with reduced rachides and well-developed inflorescence bracts and calyx lobes (Fig. 4).

2) Rigiolepis sensu Hooker which comprises the 'leptanthum-acuminatissimum' complex as described by Copeland (1932).

3) The 'uniflorum' complex sensu Copeland (1932) in which the inflorescence is reduced to a single small flower on a short pedicel.

The type for the section was chosen by Sleumer (1941) and designated as V. borneensis (Hook.f.) W.W. Sm. Unfortunately, this combination cannot stand: Rigiolepis borneense Hook.f. refers to a taxon also known as Vaccinium acuminatissimum Miq. whilst the protologue of $V$. borneense W.W. Sm. describes a plant with a much contracted inflorescence whose few flowers have costate calyx lobes, i.e., a shrub quite similar to $V$. lobbii but with much larger 3(-7)-plinerved leaves.

However, after several diligent searches, the type designated by Smith (1915) cannot be located at E effectively rendering $V$. borneense W.W. Sm. a nomen nudum. To ensure nomenclatural stability for this taxon, the following specimen is proposed as the lectotype: Native collector 1503, Sarawak, Borneo (LT: L!). 


\section{TAXONOMY}

Vaccinium section Rigiolepis (Hook.f.) Sleumer (1941) 419. - Type: Vaccinium acuminatissimum Miq.

Racemes (very) slender, often in fascicles, few- to many-flowered, sometimes reduced to a single axillary flower. Corolla small, urceolate, membranous, shortly 5-lobed. Stamens 10 , anthers or filaments furnished with a pair of short, sometimes inconspicuous awns or bristles; tubules \pm as long as cells, opening with introrse slits. Berries small, yellow, orange, or red, apparently 10-loculed, each locule containing a large seed with a thin testa.

Distribution - Borneo, especially northern Borneo, Peninsular Malaysia, northern Sumatra, and Java. According to Argent (1996) taxa belonging to this section are often overlooked in the field and may not be as rare as herbarium collections suggest. Nonetheless, on Mt Kinabalu, the summit of Borneo, repeated excursions have revealed only two taxa, viz., V. uroglossum Sleumer, an uncommon epiphyte in montane forests between 1500 and $1850 \mathrm{~m}$ altitude, and V. moultonii Merr. known only from a single collection (Argent, 1996).

\section{KEY TO THE SPECIES}

1a. Inflorescence bracts common, often persisting until fruiting; pedicular bracts well developed, often clasping the calyx tube; calyx lobes prominent, often strongly

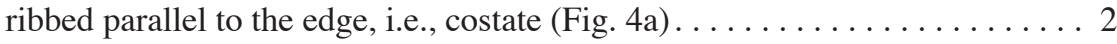

b. Inflorescence bracts small, few, and soon deciduous; pedicular bracts small or absent; calyx lobes non-costate, and apparently small in fruit (Fig. 6b) . . . . . 4

2a. Leaves with a prominent midvein, $<3 \mathrm{~cm}$ wide $\ldots \ldots \ldots \ldots \ldots$. V. lobbii

b. Leaves obviously $3(-7)$-plinerved, usually $>3 \mathrm{~cm}$ wide. . . . . . . . . 3

3a. Inflorescence contracted, rachis $<1 \mathrm{~cm}$ long. . . . . . . 2. V. suberosum

b. Inflorescence well developed, rachis $1-4 \mathrm{~cm}$ long . . . . . 3. V. borneense

4a. Rachis absent or $<30 \mathrm{~mm}$ long; flowers $<10 \ldots \ldots \ldots \ldots \ldots \ldots$

b. Rachis well developed, often slender and in fascicles, each bearing 10-30 small

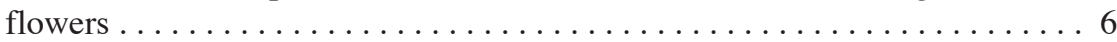

5a. Rachis absent or $<1 \mathrm{~mm}$ long; flowers 1 or 2 per leaf axil. . . 4. V. uniflorum

b. Rachis 1-30 mm long; flowers $3-10$ per rachis . . . . . 5. V. minimiflorum

6a. Leaves large, often $>4 \mathrm{~cm}$ wide or $>14 \mathrm{~cm}$ long $\ldots \ldots \ldots \ldots \ldots$

b. Leaves smaller, $<4 \mathrm{~cm}$ wide, $<14 \mathrm{~cm}$ long $\ldots \ldots \ldots \ldots \ldots \ldots \ldots$

7a. Leaves distinctly $3(-7)$-plinerved, lateral veins prominent . . . . . . . . .

6. V. acuminatissimum

b. Leaves faintly 3(-7)-plinerved, often quasi pinnate . . . . 7. V. megaphyllum

8a. Leaves with a prominent midvein, lateral veins absent or poorly developed . . 9

b. Leaves predominantly penninerved, often reticulate on both sides . . . . . . 12

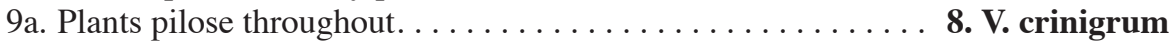

b. Plants glabrous to pubescent $\ldots \ldots \ldots \ldots \ldots \ldots \ldots \ldots \ldots \ldots \ldots \ldots \ldots \ldots$

10a. Leaves usually $<10 \mathrm{~mm}$ wide $\ldots \ldots \ldots \ldots \ldots \ldots \ldots$ 9. V. linearifolium

b. Leaves usually $>10 \mathrm{~mm}$ wide $\ldots \ldots \ldots \ldots \ldots \ldots \ldots \ldots \ldots$

11a. Leaves usually $<6 \mathrm{~cm}$ long $\ldots \ldots \ldots \ldots \ldots \ldots \ldots \ldots$. V. uroglossum

b. Leaves usually $>7 \mathrm{~cm}$ long $\ldots \ldots \ldots \ldots \ldots \ldots \ldots \ldots$ 11. V. leptanthum 
12a. Leaves $<6 \mathrm{~cm}$ long, blade glabrous beneath. . . . . . . 12. V. andersonii

b. Leaves $>11 \mathrm{~cm}$ long, blade punctuate beneath . . . . . . . 13. V. moultonii

1. Vaccinium lobbii (Ridl.) Sleumer - Map 1

Vaccinium lobbii (Ridl.) Sleumer (1941a) 168. - Rigiolepis lobbii Ridl. (1922) 107. - Type: Lobb s.n. (holo K), Sarawak.

Vaccinium lancifolium (Ridl.) Sleumer (1941a) 168. - Rigiolepis lancifolium Ridl. (1922) 106. - Type: Haviland 619 (holo K), Sarawak.

Epiphytic, scandent, rarely straggling terrestrial shrub with a well-developed lignotuber; stems slender often virgate, current shoots densely pubescent; leaves ovate-lanceolate, $2-6$ by $1-2 \mathrm{~cm}$, margin entire with two basal glands, petioles c. $1 \mathrm{~mm}$ long, abaxial blade glabrous with a prominent midvein, racemes axillary, densely pubescent, 2-5flowered, rachis and pedicels very short or absent, calyx lobes costate, prominent and remaining green in fruit, corollas tiny, c. $2 \mathrm{~mm}$ long, white or cream, sweetly scented; stamens c. $2 \mathrm{~mm}$ long; style papillose, c. $2 \mathrm{~mm}$ long; berry 4-6 mm diam., yellow or orange, 10-loculed; seeds $2-3 \mathrm{~mm}$ long, testa very thin.

Distribution - Borneo (Sarawak).

Note - Once found growing on limestone. In bloom from March until September; fruiting: September until October. The only differences between V. lobbii and $V$. lanceifolium are the quantity of indumentum on the young twigs and leaf shape: narrowly lanceolate ( $V$. lanceifolium) vs ovate to broadly lanceolate (V. lobbii) which is insufficient for specific status.

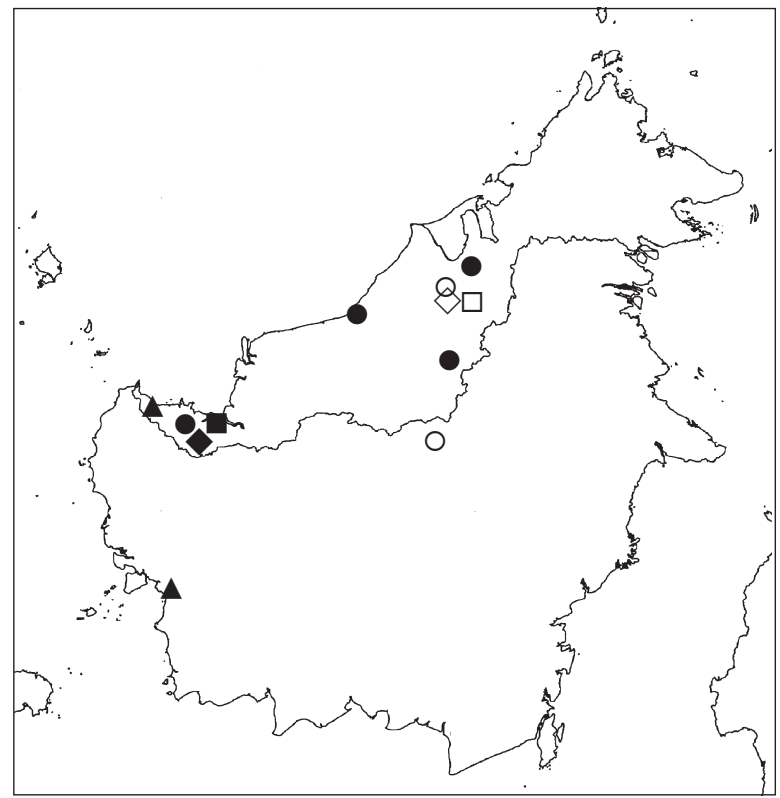

Map 1. Distribution of Vaccinium lobbii (Ridl.) Sleumer $(\diamond, \diamond)$, V. suberosum Kloet $(\mathbf{\Delta})$, V. borneense

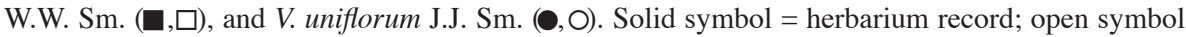
$=$ literature record. 
2. Vaccinium suberosum Kloet, spec. nov. - Fig. 3B, 4; Map 1

Affinis V. borneense W.W. Sm. sed laminis glandulosis subter atque rhachibus brevissimis differt. Frutex semi-epiphyticus cum sarmentis nunc rhizomatibus nunc reptandibus; cum ramunculis tectibus lenticellis suberosis; folia elliptica, marginis integris, supra basin utrinque glandular marginali instructa; lamina 9-15 cm longa; $3-5 \mathrm{~cm}$ lata; inflorescentia circa $1 \mathrm{~cm}$ longa, pauciflora; rhachidibus bracteolis; flores parvi, breviter pedicellati; bracteolis duobus oppositis, multicostulatis; calyx 5-partitus cum lobis prominens et multicostulatis; corolla stamina atque bacca matura haud visa. - Typus: Laman et al. 198 (L), Borneo, Kalimantan Barat, Ketapang.

Semi-epiphytic shrub with slender, corky branches; leaves elliptical $9-15$ by $3-5 \mathrm{~cm}$ wide, 3(-7)-plinerved, blade glandular beneath, margin entire, the basal gland on each side impressed on the margin c. $1 \mathrm{~cm}$ above the petiole; petiole $1-3 \mathrm{~mm}$ long, robust; bud scales short awned. Inflorescence from axillary buds scattered along the twigs, rachis pubescent, very short 1-4 mm long, bearing 1-3 flowers, inflorescence bracts few but

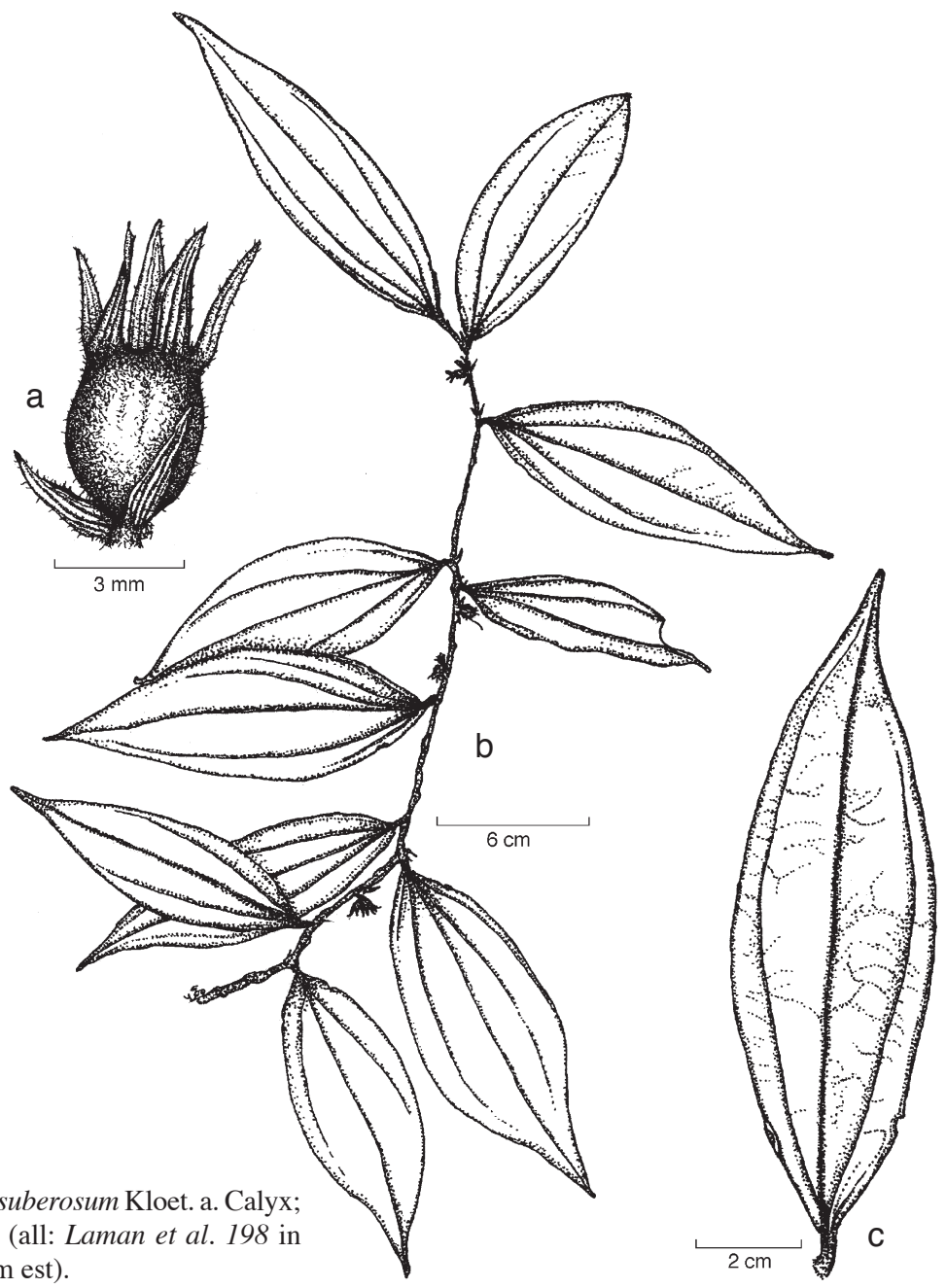

Fig. 4. Vaccinium suberosum Kloet. a. Calyx; b. ramus; c. folia (all: Laman et al. 198 in 1996 (L) depictum est). 
prominently ribbed, pedicels c. $1 \mathrm{~mm}$ long with a pair of ribbed bracts just below the calyx tube; calyx tube articulated with the pedicel, 5 calyx lobes, prominently ribbed. Corolla, style, and stamens not seen. Berries puberulent, orange, 4-5 mm diam.; seeds dark with thin testa, $2 \mathrm{~mm}$ long, c. $1 \mathrm{~mm}$ in cross section.

Distribution - Borneo (Kalimantan).

\section{Vaccinium borneense W.W. Sm. - Map 1}

Vaccinium borneense W.W. Sm. (1915) 329. - Type: Native collector 1503 (lecto L), Sarawak.

Epiphytic, scandent, or erect shrub up to $3 \mathrm{~m}$ high with a well-developed lignotuber; lateral branches stout and verrucose; leaves elliptical, $6-16$ by $2-6 \mathrm{~cm}$, margin entire with two basal glands, petioles 1-3 mm long, abaxial blade glandular-punctuate and prominently 3(-7)-plinerved; racemes axillary, densely pubescent and laxly glandular, 5-15-flowered, rachis 2-5 cm long, pedicels 1-3 cm long, calyx lobes costate, prominent and remaining green in fruit; corollas small c. $3 \mathrm{~mm}$ long, greenish white, cream, yellow, or pink, stamens c. $2 \mathrm{~mm}$ long; style glabrous, 2-3 mm long; berry 4-5 mm diam., yellow or orange, 10-loculed; seeds c. $2 \mathrm{~mm}$ long, testa very thin.

Distribution - Borneo (Sarawak).

Note - Found in variety of habitats, e.g., swamps, montane forests and rocky outcroppings, 300-2000 m altitude. In bloom from April until October; fruiting: September until January.

\section{Vaccinium uniflorum J.J. Sm. - Fig. 3E; Map 1}

Vaccinium uniflorum J.J. Sm. (1918) 68. - Type: Hallier 3296 (holo L), Borneo. Vaccinium monanthum Ridl. (1922) 108. - Type: Haviland \& Hose 3465 (holo K), Sarawak.

Epiphytic, rarely terrestrial shrub with a well-developed lignotuber; stems slender and trailing up to $3 \mathrm{~m}$ long; young branches and twigs usually pubescent; leaves elliptical, $2-6$ by $1-2 \mathrm{~cm}$, margin entire with two small basal glands, petiole c. $1 \mathrm{~mm}$ long, abaxial blade \pm pubescent and sometimes laxly glandular with a prominent midvein; flowers axillary and solitary (or occasionally in fascicles of two), pedicel c. $3 \mathrm{~mm}$ long, slender, glabrous to hirsute, calyx small, glabrous to hirsute, corolla urceolate, c. $2 \mathrm{~mm}$ long, greenish pink, white, cream, or yellow, pubescent or not; stamens c. 2 mm long; style glabrous, c. $2 \mathrm{~mm}$ long; berry 4-5 mm diam., usually orange, 10-loculed; seeds c. $1.5 \mathrm{~mm}$ long, testa thin.

Distribution - Borneo (Sarawak).

Note - A common epiphyte, ubiquitous but often overlooked, twice found growing on limestone. In bloom from April until December; fruiting: July until December. Vaccinium monanthum represents the glabrous and $V$. uniflorum the pubescent extreme of the indumentation spectrum that defines this taxon where most plants are neither completely glabrous nor completely pubescent.

\section{Vaccinium minimiflorum Sleumer - Fig. 3A; Map 2}

Vaccinium minimiflorum Sleumer (1941) 162. - Type: Richards 2103 (K n.v.), Sarawak, Ulu Koyan. 




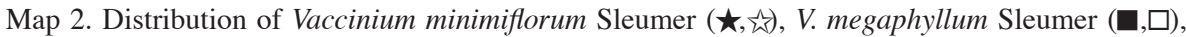
V. crinigrum Kloet $(\boldsymbol{\Delta})$, V. uroglossum Sleumer $(\bullet, \bigcirc)$, and V. andersonii Sleumer $(\diamond, \diamond)$. Solid symbol $=$ herbarium record; open symbol $=$ literature record.

Epiphytic shrub with puberulent twigs; leaves elliptical, $3-7$ by $1-2 \mathrm{~cm}$, margin entire with two small basal glands, petiole 1-2 mm long, abaxial blade glandular-punctuate with a prominent midvein, occasionally weakly 3(-7)-plinerved; racemes axillary, pubescent and \pm glandular, 3-7-flowered, rachis 2-40 mm long, pedicels 1-2 mm long, calyx very small, corolla urceolate, c. $3 \mathrm{~mm}$ long, greenish white or yellow; stamens c. $3 \mathrm{~mm}$ long, style glabrous, c. $3 \mathrm{~mm}$ long; berry 4-5 mm diam., orange-red, 10-loculed; seeds c. $2 \mathrm{~mm}$ long, testa thin.

Distribution - Borneo (Sarawak).

Note - In bloom from April until August; fruiting: August until December. Except for the presence of a rachis and multiple flowers, similar to V. uniflorum.

\section{Vaccinium acuminatissimum Miq. - Fig. 3G; Map 3}

Vaccinium acuminatissimum Miq. (1863) 36. - Type: Blume 2045 (lecto L), Java. Gaylussacia lanceolata Blume (1825) 861. - Type: Blume 2045 (lecto L), Java. Rigiolepis borneensis Hook.f. (1876) 54, t. 1160. - Type: Lobb s.n. (lecto K), Sarawak. Vaccinium bigibbum J.J. Sm. (1918) 408. - Type: Teijsmann 7966 (holo L), Borneo. Vaccinium sulcatum Ridl. (1922) 107. - Type: Beccari 3780 (holo K), Sarawak. Rigiolepis poiana J.J. Sm. (1935) 327. - Type: Foxworthy 395 (holo K), Sarawak. Rigiolepis korthalsii J.J. Sm. (1935) 334. - Type: Korthals s.n. (holo L), Borneo. Vaccinium dipladenium Sleumer (1941a) 168. - Type: Korthals s.n. (holo L), Borneo. Vaccinium piperifolium Sleumer (1961) 20. - Type: Clemens 21696 (n.v.), Sarawak, Gat, Upper Rejang River. 


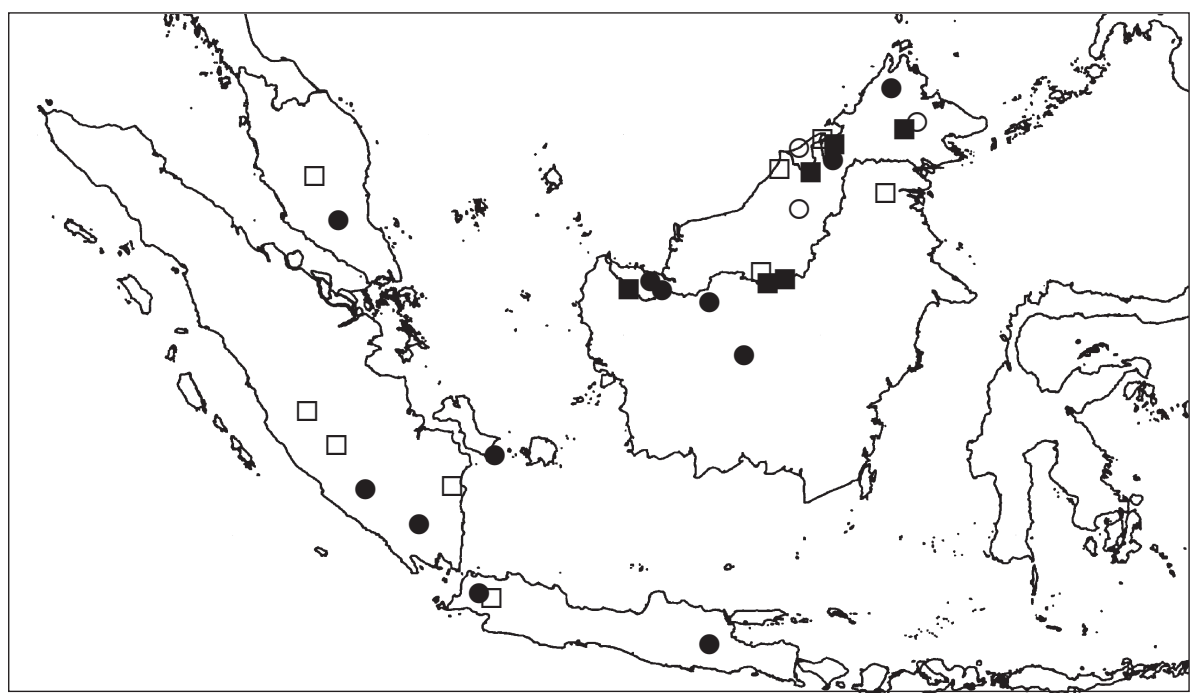

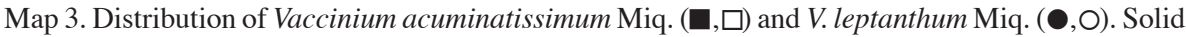
symbol $=$ herbarium record; open symbol $=$ literature record.

Epiphytic, scandent, or terrestrial shrub up to $5 \mathrm{~m}$ high; older branches often corky, current shoots or branches densely pubescent and/or glandular; leaves lanceolate, apex acuminate to caudate, $10-20$ by $4-6 \mathrm{~cm}$, margin entire with two, often prominent, basal glands, petioles c. $5 \mathrm{~mm}$ long, abaxial blade 3(-7)-plinerved, often with conspicuous connecting lateral nerves, glandular, punctuate or pubescent; racemes axillary often in fascicles, glandular and/or pubescent, 10-30-flowered, rachis 3-7 cm long, pedicels 2-4 mm long; calyx small, corolla urceolate, 2-3 mm long, white or cream; stamens c. $2 \mathrm{~mm}$ long, style glabrous, 2-3 mm long; berry 4-5 mm diam., yellow, orange, or red, 10-loculed; seeds 2-3 mm long, testa thin and black.

Distribution - Sumatra, Peninsular Malaysia, Borneo, and Java.

Note - Found in swamps, marshes, and forests, 360-1400 m altitude. Blooms and fruits throughout the year. Most of the taxonomic difficulty ascribed to this taxon stems from the notion that Rigiolepis borneensis Hook.f. and V. borneense W.W. Sm. refer to the same taxon. Accepting Boerlage's (1891) reduction of $R$. borneensis as just a form of $V$. acuminatissimum, all other named extremes of leaf variation can similarly be reduced to forms of $V$. acuminatissimum.

\section{Vaccinium megaphyllum Sleumer - Fig. 3C; Map 2}

Vaccinium megaphyllum Sleumer (1961) 17. - Type: Amdjah 480 (holo L), Borneo. Rigiolepis macrophylla J.J. Sm. (1935) 335. - Type: Amdjah 480 (holo L), Borneo. Vaccinium macrophyllum (J.J. Sm.) Sleumer (1941a) 168. - Type: Amdjah 480 (holo L), Borneo.

Epiphytic, scandent, or terrestrial shrub up to $5 \mathrm{~m}$ high; older branches often corky, current shoots and branches densely pubescent; leaves broadly lanceolate, apex often caudate, $15-30$ by $6-10 \mathrm{~cm}$, margin entire with two, often obscure, basal glands, 
petioles 4-10 $\mathrm{mm}$ long, blade quasi pinnate, often punctuate beneath; racemes axillary, often in fascicles, pubescent or puberulent, $10-30$-flowered; rachis $2-6 \mathrm{~cm}$ long, pedicels $2-4 \mathrm{~mm}$ long, calyx small, corolla urceolate, $2-3 \mathrm{~mm}$ long, white or cream; stamens c. $2 \mathrm{~mm}$ long, style glabrous, $2-3 \mathrm{~mm}$ long; berry $4-5 \mathrm{~mm}$ diam., yelloworange, 10-loculed; seeds $2-3 \mathrm{~mm}$ long, testa thin and black.

Distribution - Borneo.

Note - This taxon is rarely collected thus precludes comments on ecology and biology.
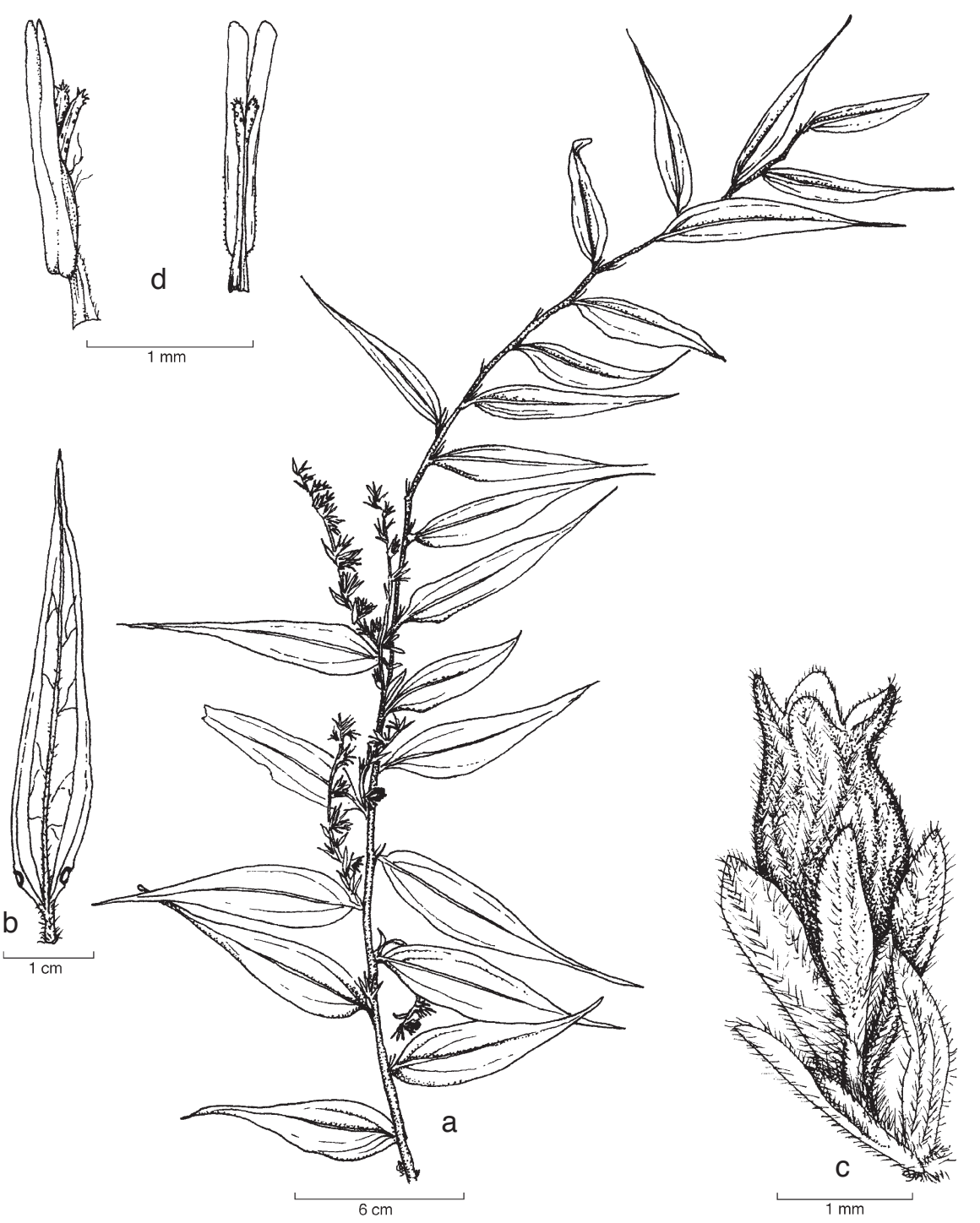

Fig. 5. Vaccinium crinigrum Kloet. a. Ramus; b. folia; c. flos; d. stamen (all: Burtt \& Woods B2781 in 1962 (L) depictum est). 
8. Vaccinium crinigrum Kloet, spec. nov. - Fig. 5; Map 2

Affinis V. lanceifolium (Ridl.) Sleumer sed racemis perlongioribus atque calycis lobis minoribus costulatis differt. Frutex epiphyticus; pilosum per totum; cum ramunculis flexibilibus; folia lanceolata, margins integris, supra basin utrinque glandula marginali instructa; lamina 6-8 cm longa, 1-2 cm lata; inflorescentia 4-6 cm longa, multiflora; rhachidibus bracteolis; flores parvi, breviter pedicellati; bracteolis duobus opposites; calyx 5-partitus, cum lobis prominens; corolla parva urceolata rubra; bacca matura haud visa. - Typus: Burtt \& Woods B 2781 (L), Sarawak, Primus Divisio, Poi montosus, Mons Berumput, $1200 \mathrm{msm}, 1962$.

Epiphytic shrub with slender pilose branches. Leaves lanceolate, 6-8 by 1-2 cm, densely pilose when young, margin entire, with two basal glands strictly marginal; petiole 1-2 $\mathrm{mm}$ long, pilose; bud scales long awned and pilose. Inflorescence in axillary racemes bearing $8-15$ flowers, densely pilose, especially the calyx tube, rachis slender, 4-6 cm long, bearing many attenuated bracts, pedicels $1-4 \mathrm{~mm}$ long at anthesis with one basal bract and two similar bracts, the latter immediately below the calyx, \pm lanceolate and weakly ribbed; calyx tube articulated with pedicel, 5 prominent calyx lobes, c. 3 $\mathrm{mm}$ long, terminating in a pair of bristles; anthers c. $1 \mathrm{~mm}$ long; anther tubules c. 0.7 $\mathrm{mm}$ long, opening with a small introrse pore. Berries and seeds not seen.

\section{Vaccinium linearifolium Kloet, spec. nov. - Fig. 3F, 6; Map 4}

Affinis V. tenerellum Sleumer sed foliis perlongioribus atque angustioribus, laminis glabratibus, gemmis cum squamis aristis perlongioribus differt. Frutex epiphyticus; rarum pilosum aut pubescentem; cum ramunculis flexibilibus; folia lineara, marginis integris, petiolis crassis; $1 \mathrm{~mm}$ longis; lamina 11-13 cm longa, 7-9 mm lata; inflorescentia 3-5

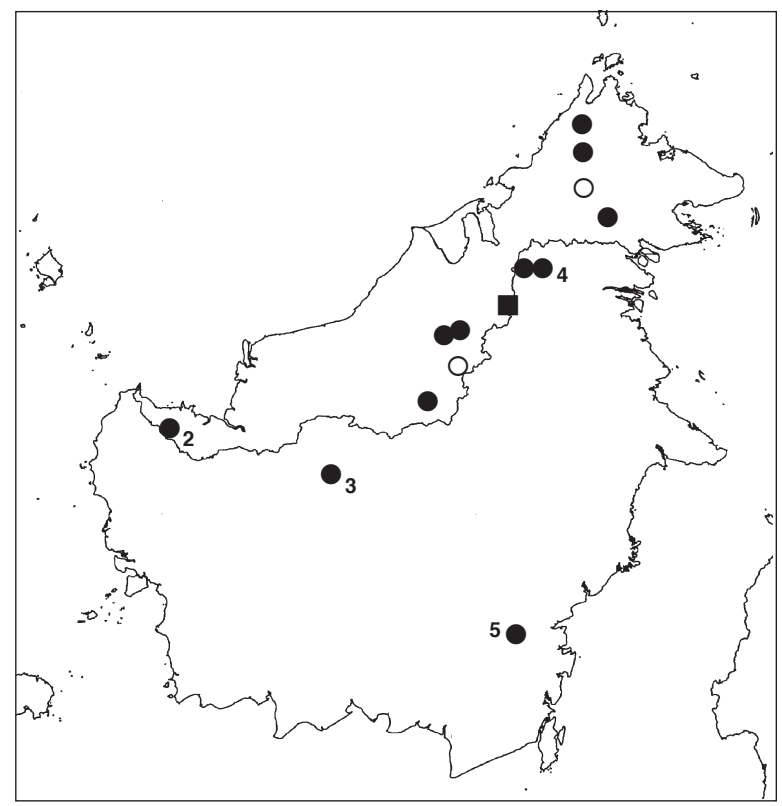

Map 4. Distribution of Vaccinium linearifolium Kloet (ם) and V. moultonii Merr. $(\bullet, 0)$. Solid symbol $=$ herbarium record; open symbol $=$ literature record. 
cm longa, multiflora; rhachidibus bracteolis; flores parvi, breviter pedicellati; bracteolis duobus oppositis; calyx 5-partitus, cum lobis prominens, corolla parva, globosa, alba; bacca matura haud visa. - Typus: Yii S 55984 (L), Sarawak, Quartus Divisio, Kebalit terra alta, $1580 \mathrm{msm}, 1988$.

Epiphytic shrub with slender, \pm pubescent, branches. Leaves linear, $11-13 \mathrm{~cm}$ by $7-9$ $\mathrm{mm}, \pm$ glabrous, margin entire; petiole $1 \mathrm{~mm}$ long, stout, \pm pilose, with a pair of small glands imbedded along the edge; bud scales long awned. Inflorescence in axillary racemes bearing $7-11$ flowers, weakly pilose, rachis slender $3-5 \mathrm{~cm}$ long, bearing many
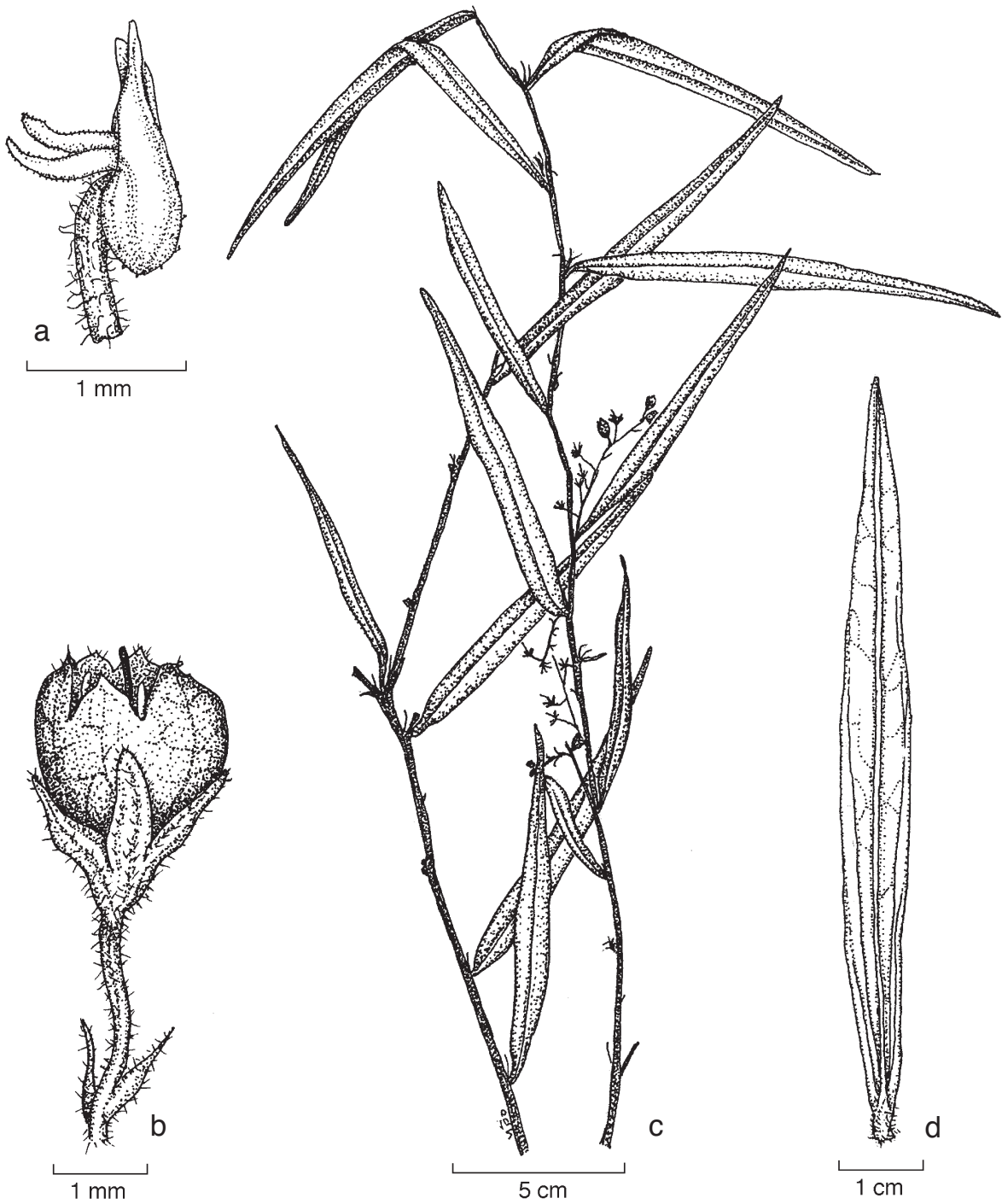

Fig. 6. Vacciunium linearifolium Kloet. a. Stamen; b. flos; c. ramus; d. folia (all: Yii S 55984 in 1988 (L) depictum est). 
small, short lived bracts, pedicels c. $3 \mathrm{~mm}$ long at anthesis with a pair of bracts inserted towards the base of the pedicel; calyx tube small, scarcely articulated with pedicel at anthesis, 5 calyx lobes, c. $1 \mathrm{~mm}$ long; corolla globose, 5-lobed, 4-5 mm diam., c. 3 mm long, white; style slender, glabrous, c. 4 mm long; stamens 10, c. $2 \mathrm{~mm}$ long, free filament c. $1 \mathrm{~mm}$ long, pilose, terminating in a pair of bristles; anthers c. $1 \mathrm{~mm}$ long, opening into an oval pore. Berries and seeds not seen.

\section{Vaccinium uroglossum Sleumer - Map 2}

Vaccinium uroglossum Sleumer (1941a) 166. - Type: Clemens 40802 (holo K), Borneo. Vaccinium tenerellum Sleumer (1961) 18. - Syntypes: Brunig s.n., Sarawak, Marigan Range; BRUN 2300, 2404, Brunei, G. Pagon; BRUN 2387, Brunei, summit of Pagon Priok (all n.v.).

Epiphytic, scandent, or erect shrub, 1-5 m high, with a well-developed lignotuber; lateral branches slender and pubescent; leaves ovate to lanceolate, $4-8$ by $1-3 \mathrm{~cm}$, apex acuminate to caudate, margin entire and usually with two small basal glands, petioles c. $1 \mathrm{~mm}$ long, blade weakly 3(-7)-plinerved or with a prominent midvein, often glandular pubescent when young but glabrous with age; racemes axillary, densely pubescent and/or glandular, 10-20-flowered; rachis slender, 4-6 cm long, pedicels slender, 2-4 mm long, calyx $<2 \mathrm{~mm}$ long, corollas urceolate, 3-5 cm long, yellowgreen or cream; stamens c. $3 \mathrm{~mm}$ long, style glabrous, 3-4 mm long; berry 4-5 mm diam., yellow-orange, 10-loculed; seeds c. $2 \mathrm{~mm}$ long, testa thin.

Distribution - North Borneo, Sarawak, Brunei.

Note - Flowering and fruiting throughout the year. According to Argent (1996) $V$. tenerellum is but a robust form of $V$. uroglossum.

\section{Vaccinium leptanthum Miq. - Fig. 3D, 7; Map 3}

Vaccinium leptanthum Miq. (1863) 37. - Type: Herb. Lugd. Bat. 909, 92 (lecto L), Java. (Although this specimen has no date nor collector, the annotation is in Miquel's hand and thus was chosen as the type for this species.)

Vaccinium flagellatifolium H.F. Copel. (1930) 567. - Type: Native collector 1679 (holo US), Sarawak.

Rigiolepis salicifolia J.J. Sm. (1935) 336. - Type: Endert 4100 (holo L), Borneo.

Vaccinium capillipes Sleumer (1941a) 168. - Type: Endert 4100 (holo L), Borneo.

Epiphytic, scandent, or terrestrial shrub, 1-3(-20) m high, with a small lignotuber; branches slender, corky when old, pubescent when young; leaves narrowly lanceolate, $8-12$ by $1-2 \mathrm{~cm}$, apex acuminate to caudate, margin entire with one or two (rarely none) basal glands, petioles 3-4 mm long, abaxial blade with a prominent midvein often glandular pubescent when young but \pm glabrous with age; racemes axillary, often in fascicles, puberulent, 10-20-flowered, rachis slender, 4-7 cm long, pedicels slender to filiform, 4-6 mm long, calyx $<2 \mathrm{~mm}$ long, corolla urceolate, 2-3 $\mathrm{mm}$ long, thin, whitish yellow, stamens c. $2 \mathrm{~mm}$ long, style glabrous, c. $2 \mathrm{~mm}$ long; berry 3-5 mm diam., yellow to orange, 10-loculed; seeds 2-3 mm long, testa white, embryo green.

Distribution - Sumatra, Peninsular Malaysia, Borneo, and Java.

Notes - Once found on limestone; usually epiphytic from mangrove swamps to primary forests at $1000 \mathrm{~m}$ altitude. According to Miquel (1863) the singular features of this taxon were its small flowers and narrow leaves. Vaccinium flagellatifolium and 


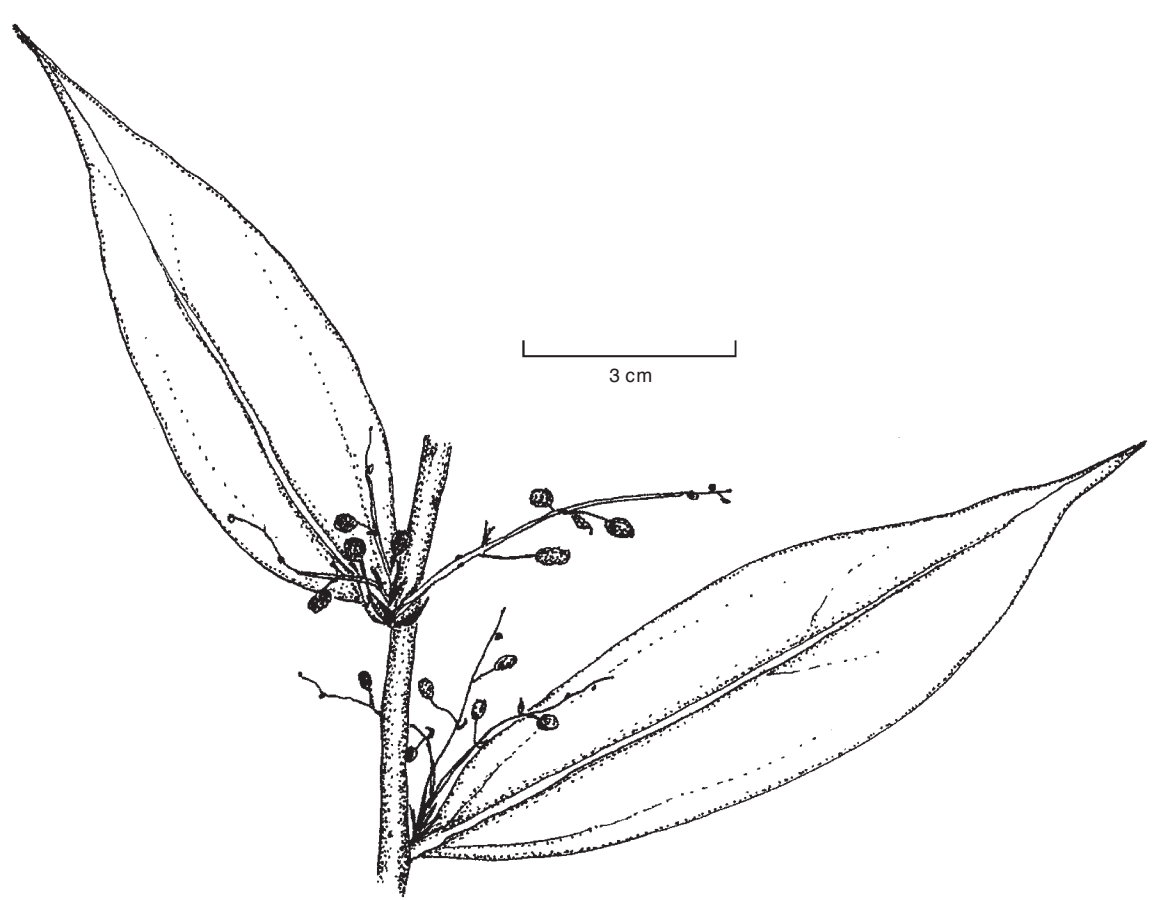

Fig. 7. Fascicle of inflorescences from several perennating buds in the axil of a single leaf of Vaccinium leptanthum Miq.

$V$. capillipes only differ from $V$. leptanthum by having long caudate apices in the former and the impression of lateral vein development in the latter, both of which are quite plastic depending on the persistence of precipitation.

Vaccinium leptanthum is a shrub with trailing stems, usually 1-3 m long but occasionally, especially when the plant is epiphytic, one of those stems begins to climb through the canopy and may lengthen to 10 up to $20 \mathrm{~m}$ depending on the height of the tree.

\section{Vaccinium andersonii Sleumer - Fig. 3I; Map 2}

Vaccinium andersonii Sleumer (1963) 124. - Type: Anderson 4704 (L, fragm.), Sarawak, Baram Distr., G. Api.

Epiphytic shrub; older branches with raised lenticels, young branches and shoots glabrous; leaves ovate-elliptical, $4-6$ by $2-4 \mathrm{~cm}$, margin entire with two basal glands, petioles 2-4 mm long, blade glabrous and faintly 3(-7)-plinerved or penninerved, reticulate on both sides; racemes axillary, glandular and/or pubescent, 7-15-flowered, rachis 4-7 cm long, rather stout, pedicels 2-4 mm long, calyx small, corolla urceolate, c. $4 \mathrm{~mm}$ long, white or yellow, stamens c. $2 \mathrm{~mm}$ long, style slender, pubescent, c. 3 mm long; berry 4-5 mm diam., yellow-orange, 10-loculed; seeds c. $2 \mathrm{~mm}$ long, testa thin and black.

Distribution - Borneo (Sarawak). 


\section{Vaccinium moultonii Merr. - Fig. 3H; Map 4}

Vaccinium moultonii Merr. (1923) 22. - Type: Moulton 6676 (holo K), Sarawak.

Rigiolepis endertii J.J. Sm. (1935) 339. - Type: Endert 3883 (holo L), Borneo.

Rigiolepis filiformis J.J. Sm. (1935) 340. - Type: Endert 4041 (holo L), Borneo.

Vaccinium filiforme (J.J. Sm.) Sleumer (1941a) 168. - Type: Endert 4041 (holo L), Borneo.

Vaccinium kemulense Sleumer (1941a) 168. - Type: Endert 3883 (holo L), Borneo.

Epiphytic, scandent, or terrestrial shrub up to $4 \mathrm{~m}$ high; older branches with raised lenticels, current shoots and branches puberulent or pubescent; leaves lanceolate, 8-16 by $3-7 \mathrm{~cm}$, apex acuminate to caudate, margin entire with two basal glands, petioles c. $5 \mathrm{~mm}$ long, blades quasi-penninerved, punctuate beneath; racemes axillary, often in fascicles, pubescent and/or glandular, 10-20-flowered, rachis 2-6 cm, pedicels 2-5 $\mathrm{mm}$ long, calyx c. $2 \mathrm{~mm}$ long, corolla urceolate, 3-4 mm long, white, yellow or cream, stamens c. $2 \mathrm{~mm}$ long, style glabrous, 2-3 mm long; berry 4-5 mm diam., yellow, orange, or red, 10-loculed; seeds c. $2 \mathrm{~mm}$ long, testa thin and black.

Distribution - Borneo (Sarawak and N Borneo).

Note - Occurs in variety of habitats, e.g., swamps, riverine forest, montane forests, and sandy ridges; blooms and fruits throughout the year. The differences among these taxa focus on apparent secondary and tertiary vein development, which are trivial and plastic.

\section{EXCLUDED TAXA}

Vaccinium adenopodum Sleumer (1961) 21.

No specimens seen.

Vaccinium henrici Sleumer (1941a) 161.

Its characteristics suggest affinity to V. bacanum Miq. and V. clementis Merr. of Vaccinium section Bracteata Nakai and not section Rigiolepis as alleged by Sleumer (1967).

\section{REFERENCES}

Argent, G. 1996. The rhododendron and blueberry family. In: K.M. Wong \& A. Philips (eds.), Kinabalu, the summit of Borneo: 181-201. Sabah Parks, Kota Kinabalu, Malaysia.

Blume, C.L. 1825. Gaylussacia lanceolata. Bijdragen tot de Flora van Nederlandsch Indië 15: 860861.

Boerlage, J.G. 1891 ('1899'). Handl. Fl. Ned. Ind. 2: 263.

Copeland, H.F. 1930. Philippine Ericaceae II: The species of Vaccinium. Philipp. J. Sci. 42: 537604.

Copeland, H.F. 1932. Philippine Ericaceae III: Taxonomic revision. Philipp. J. Sci. 47: 57-115.

Hooker, W.J. 1876. Rigiolepis borneensis. Icones Plantarum: 54, t. 1160.

Merrill, E.D. 1923. New or noteworthy Bornean plants. J. Straits Branch Roy. Asiat. Soc. 87: 1944.

Miquel, F.A.W. 1863. Ericaceae Archipelagi Indici. Ann. Mus. Bot. Lugduno-Batavia 1: 36-45.

Kron, K.A., E.A. Powell \& J.L. Luteyn. 2002. Phylogenetic relationships within the blueberry tribe (Vaccinieae, Ericaceae) based on sequence data from matK and nuclear ribosomal ITS regions, with comments on the placement of Satyria. Amer. J. Bot. 89: 327-336.

Powell, E. A. \& K.A. Kron. 2002. Hawaiian blueberries and their relatives - A phylogenetic analysis of Vaccinium sections Macropelma, Myrtillus and Hemimyrtillus (Ericaceae). Syst. Bot. 27: $768-779$. 
Ridley, H.N. 1922. Rigiolepsis and other Vacciniaceae of Borneo. Bull. Misc. Inform. Kew (1922): $106-114$.

Sleumer, H. 1941a. Neue Ericaceen aus Malesien. Bot. Jahrb. Syst. 71: 138-168.

Sleumer, H. 1941b. Vaccinioideen studien. Bot. Jahrb. Syst. 71: 375-510.

Sleumer, H. 1961. Florae Malesianae Precursores XXVIII, The genus Vaccinium in Malaysia. Blumea 11: 9-107.

Sleumer, H. 1963. Florae Malesianae Precursores XXXV, Supplementary notes towards the knowledge of the Ericaceae in Malaysia. Blumea 12: 89-171.

Sleumer, H. 1967. Vaccinium. In: C.G.G.J. van Steenis (ed.), Flora Malesiana, ser. I, vol. 6: 746-878. Groningen: Wolters-Noordhoff.

Smith, J.J. 1914. Vaccinium uniflorum (Ericaceae). Icon. Bogor. 4: 67, t. 320.

Smith, J.J. 1918. Plantae novae vel criticae ex herbario et horto Bogoriense series 3: 390-411.

Smith, J.J. 1935. The Malaysian genus Rigiolepis Hooker f. Blumea 1: 323-342.

Smith, W.W. 1915. Species borneenses. Notes Roy. Bot. Gard. Edinburgh 8: 315-329.

Stevens, P.F. 1969. Taxonomic studies in the Ericaceae. Unpublished D. Phil. Thesis, University of Edinburgh, Edinburgh.

\section{INDEX}

The accepted names are in roman type, the synonyms and excluded taxa (excl.) in italics and the new names in bold. The number after each name is the number of the species in the text.

Agapetes D. Don [p. 477, 478, 482, 483]

Costera J.J. Sm. [p. 477]

Dimorphanthera F. Muell. [p. 477]

Gaylussacia Humb., Bonpl. \& Kunth [p. 478] lanceolata Blume 6

Rigiolepis Hook.f. borneënsis Hook.f. 6

endertii J.J. Sm. 13

filiformis J.J. Sm. 13

korthalsii J.J. Sm. 6

lancifolium Ridl. 1

lobbii Ridl. 1

macrophylla J.J. Sm. 7

poiana J.J. Sm. 6

salicifolia J.J. Sm. 11

Vaccinium L.

section Aethopus Airy Shaw [p. 482]

section Bracteata Nakai [p. 495]

section Ciliata Nakai [p. 478]

section Conchophyllum Sleumer [p. 478]

section Galeopetalum (J.J. Sm.) Sleumer [p. 478, 482]

section Rigiolepis (Hook.f.) Sleumer

[p. 477, 478, 479, 482, 483, 484]

acuminatissimum Miq. 6

adenopodum Sleumer excl.

andersonii Sleumer 12

bacanum Miq. [p. 495]

bigibbum J.J. Sm. 6

borneense W.W. Sm. 3
(Vaccinium)

capillipes Sleumer 11

clementis Merr. excl.

crassifolium Andrews [p. 477]

crinigrum Kloet 8

dipladenium Sleumer 6

filiforme (J.J. Sm.) Sleumer 13

flagellatifolium H.F. Copel. 11

gaultheriifolium (Griff.) Hook.f. [p. 478]

henrici Sleumer excl.

kemulense Sleumer 13

lancifolium (Ridl.) Sleumer 1

leptanthum Miq. 11

linearifolium Kloet 9

lobbii (Ridl.) Sleumer 1

macrophyllum (J.J. Sm.) Sleumer 7

megaphyllum Sleumer 7

minimiflorum Sleumer 5

monanthum Ridl. 4

moultonii Merr. 13

oldhamii Miq. [p. 477]

piperifolium Sleumer 6

ridleyii Sleumer

suberosum Kloet 2

sulcatum Ridl. 6

tenerellum Sleumer 10

uliginosum L. [p. 477]

uniflorum J.J. Sm. 4

uroglossum Sleumer 10 
APPENDIX. Citation of specimens scored for the numerical analyses.

\begin{tabular}{|c|c|c|c|}
\hline OTU & Provenance & Collector(s) & Determinavit \\
\hline 1 & Sarawak & Mohtar et al. S 51469 (L) & V. uniflorum \\
\hline 2 & Sarawak & Mohtar et al. S 51440 (L) & V. uniflorum \\
\hline 3 & Sarawak & Mohtar \& Othman S 49794 (L) & V. uniflorum \\
\hline 4 & Sarawak & Mohtar et al. S 49640 (L) & V. uniflorum \\
\hline 5 & Sarawak & Kessler $276(\mathrm{~L})$ & V. suberosum \\
\hline 6 & Kalimantan Barat & Laman et al. $198(\mathrm{~L})$ & V. suberosum \\
\hline 7 & Sarawak & Burtt \& Woods 1937 (L) & V. lobbii \\
\hline 8 & Sarawak & Lee $S 54644(\mathrm{~L})$ & V. megaphyllum \\
\hline 9 & Kalimantan Timur & Geesink $9104(\mathrm{~L})$ & V. andersonii \\
\hline 10 & Sarawak & Lee $S 44043(\mathrm{~L})$ & V. borneense \\
\hline 11 & Sarawak & Mohtar S 48115 (L) & V. moultonii \\
\hline 12 & Kalimantan, Kalteng & Jarvie \& Ruskandi 5148 (L) & V. megaphyllum \\
\hline 13 & Sarawak & Kessler 194 (L) & V. acuminatissimum \\
\hline 14 & Sabah & Madani 132727 (L) & V. moultonii \\
\hline 15 & Kalimantan South & Leeuwenberg \& Rudjiman 13414 (L) & V. leptanthum \\
\hline 16 & Sarawak & Lee $S 54673(\mathrm{~L})$ & V. leptanthum \\
\hline 17 & Kalimantan Barat & Laman et al. $1288(\mathrm{~L})$ & V. leptanthum \\
\hline 18 & Sarawak & Chai S 39712 (L) & V. leptanthum \\
\hline 19 & Sarawak & Othman et al. S $57854(\mathrm{~L})$ & V. leptanthum \\
\hline 20 & Sarawak & Yü S 55984 (L) & V. linearifolium \\
\hline 21 & Kalimantan Timur & Geesink 9265 (L) & V. moultonii \\
\hline 22 & Sarawak & Awa \& Lee S 47775 (L) & V. uroglossum \\
\hline 23 & Kalimantan West & Church et al. $2376(\mathrm{~L})$ & V. uroglossum \\
\hline 24 & Sarawak & $Y \ddot{u} S 56990$ (L) & V. leptanthum \\
\hline 25 & Sarawak & Yü S $61422(\mathrm{~L})$ & V. acuminatissimum \\
\hline 26 & Sarawak & Mohtar S 48065 (L) & V. moultonii \\
\hline 27 & Sarawak & Yü S $55300(\mathrm{~L})$ & V. leptanthum \\
\hline 28 & Sarawak & Haegens et al. 534 (L) & V. andersonii \\
\hline 29 & Sarawak & Burtt \& Woods 2781 (L) & V. crinigrum \\
\hline 30 & Sarawak & Awa \& Lee S 47894 (L) & V. uroglossum \\
\hline 31 & Sarawak & Yü S $58526(\mathrm{~L})$ & V. acuminatissimum \\
\hline 32 & Kalimantan West & Zulkarnain \& Giesen 425 (L) & V. acuminatissimum \\
\hline 33 & Kalimantan West & Giesen 43 (L) & V. acuminatissimum \\
\hline 34 & Sabah & Mansus et al. $117483(\mathrm{~L})$ & V. moultonii \\
\hline 35 & Kalimantan Timur & Geesink 9192 (L) & V. leptanthum \\
\hline 36 & Kalimantan Kalteng & Jarvie \& Ruskandi 5273 (L) & V. leptanthum \\
\hline 37 & Kalimantan Central & RBGE19942267 cult. & V. acuminatissimum \\
\hline
\end{tabular}

